\title{
A MULTILEVEL CONVERTER WITH REDUCED NUMBER OF SWITCHES FOR FUEL CELL POWER CONDITIONING SYSTEM
}

\author{
${ }^{1}$ Prasada Rao, K. and ${ }^{2}$ Sukhdeo Sao \\ ${ }^{1}$ Department of EEE, Christu Jyothi Institute of Technology and Science, Jangaon, AP, India \\ ${ }^{2}$ Department of EEE, Bharath Institute of Engineering and Technology, Hyderabad, AP, India
}

Received 2014-01-19; Revised 2014-01-24; Accepted 2014-04-11

\begin{abstract}
This study investigates the potentials of cascaded five and seven level converters with reduced number of switches for fuel cell power conditioning system. Fuel cells is one of the most important sources of distributed energy because of its high efficiency, high energy density, plus high reliability and long life due to few moving parts. This study proposes a suitable multilevel converter with less number switches that fulfills the required performance specifications of a fuel cell power conditioning system. The dc-dc and dcac converters are required to produce constant magnitude and frequency voltage from fuel cells. However Switching losses in these converters reduce overall efficiency of the system. To improve the efficiency and to use in medium and high power applications, the multilevel converter with reduced number of switches is connected as dc-ac converter. To synthesize maximum levels at the output voltage, the proposed topology is optimized for various objectives, such as the minimization of the number of switches, gate driver circuits and capacitors and blocking voltage on switches. The operation and performance of the proposed multilevel converter have been evaluated by MATLAB/SIMULINK.
\end{abstract}

Keywords: Cascaded Multilevel Converter, Fuel Cell, Reduced Number of Switches, Power Conditioning System, THD

\section{INTRODUCTION}

The conventional fossil fuel energy sources such as petroleum, natural gas and coal which meet most of the world's energy demand today are being depleted rapidly. Also their combustion products are causing global problems such as the greenhouse effect and pollution which are posing great danger for our environment and eventually for the entire life on our planet. The renewable energy sources (solar, wind, Fuel cells) are attracting more attention as an alternative energy. One of these resources is solar energy. The Photovoltaic (PV) array normally uses a Maximum Power Point Tracking (MPPT) technique to continuously deliver the highest power to the load when there are variations in irradiation and temperature. The disadvantage of PV energy is that the PV output power depends on weather conditions and cell temperature, making it an uncontrollable source. Corresponding Author: Prasada Rao, K., Department of EEE, Christu Jyothi Institute of Technology and Science, Jangaon, AP, India

Furthermore, it is not available during the night. In order to overcome these inherent drawbacks, alternative sources, such as FC, should be installed in the hybrid system. By changing the FC output power, the hybrid source output becomes controllable. A fuel cell is an electrochemical cell that converts a source fuel into an electrical current. It generates electricity inside a cell through reactions between a fuel and an oxidant, triggered in the presence of an electrolyte. The reactants flow into the cell and the reaction products flow out of it, while the electrolyte remains within it. Fuel cells can operate continuously as long as the necessary reactant and oxidant flows are maintained.

The Photovoltaic (PV) array normally uses a Maximum Power Point Tracking (MPPT) technique to continuously deliver the highest power to the load when there are variations in irradiation and temperature but it has been well-proven that a photovoltaic power source Plfescience Publications 978 
should be integrated with Proton Exchange Membrane (PEM) fuel cell and making PV-FC hybrid system controllable. However, PEMFC, in its turn, works only at a high efficiency band. The hybrid system can either be connected to the main grid or islanded mode, respectively. The system under study in this dissertation is a grid-connected PVFC hybrid power system.

The dc-dc converters are required to adjust the variable and low quality output voltage of PV or fuel cells and the dc-ac converters are required for fuel cells to generate required voltage and frequency for grid connection (Gou et al., 2010). Power flow in fuel cell based multilevel converter is shown in Fig. 1. During transients to prevent membrane damage as well as detrimental degradation of the fuel cell stacks voltage and oxygen depletion, it is necessary to design better control scheme to achieve optimal air and hydrogen inlet flow rates using current drawn from fuel cell (Tanrioven and Alam, 2006).

The multilevel converters are effective in case of medium and high power applications, without increasing the voltage rating of switching components for grid connection. Due to staircase output voltage of multilevel converters harmonic's of voltage and current and hence size of the filters are reduced. Lower switching frequency of multilevel converters reduces switching losses and increases the efficiency (Babaei and Hosseini, 2009; Babaei and Moeinian, 2010).

Three different multilevel inverter topologies are the Neutral Point Clamped (NPC) or diode clamped (Nabae et al., 1981), the flying capacitor or capacitor clamped (Kazerani and Paramita, 2011) and Cascaded H Bridge (CHB) (Meynard and Foch, 1992). The Main drawbacks of NPC topology are unequal voltage sharing among series connected capacitors, DC link capacitor unbalancing and requirement of large number of clamping diodes in higher level. Capacitor clamped topology require large number of storage capacitors for higher levels. Cascaded $\mathrm{H}$ bridge topology requires large number of isolated DC voltage sources which increases the converter cost and complexity.

In multilevel converter, the power quality is improved as the number of levels increase at the output voltage. However, it increases the number of switching devices and other components, increases the cost and control complexity and tends to reduce the overall reliability and efficiency of the converter. It can be noticed that multilevel converters can sustain the operation in case of internal fault (Marchesoni et al., 1988). In case of internal fault of one cell of FC converter, the maximum output voltage remains constant, but the number of levels decreases. On the other hand, when an internal fault is detected in the CHB converter and the faulty cell is identified, it can be easily isolated through an external switch and replaced by a new operative cell.

In asymmetric topologies the values of DC voltage sources are unequal (Fazel et al., 2007). These converters reduce the size and cost of the converter and improve reliability. In hybrid multilevel converter different multilevel topologies, unequal values of DC voltage sources and different modulation techniques have been used (McGrath and Holmes, 2008). Different multilevel topologies result loss of modularity and produce problems with switching frequency.

In this study proposing a fuel cell based multilevel converter with reduced number of switches. Reduction in number of switches further reduces the switching losses and hence improves efficiency.

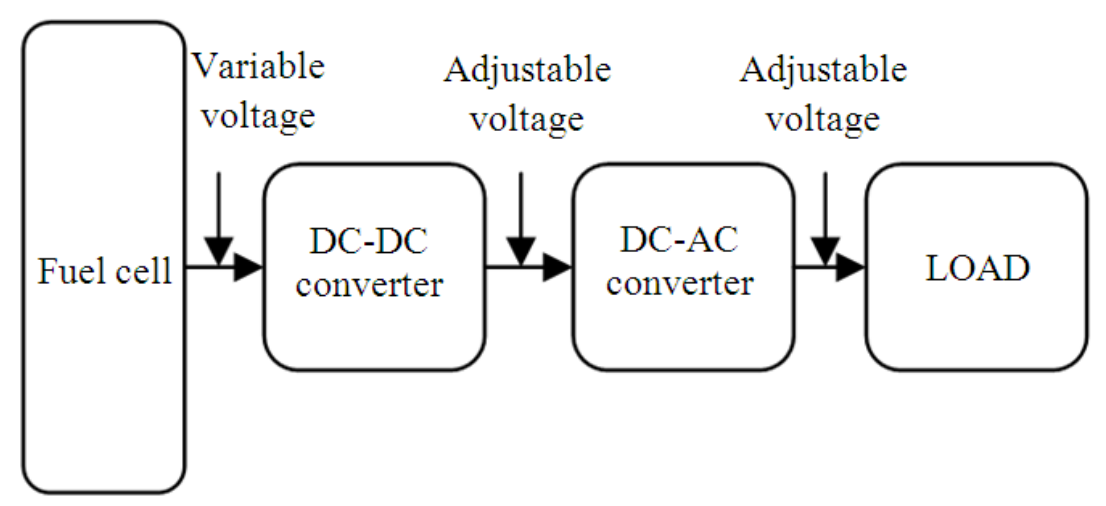

Fig. 1. Power flow in fuel cell based multilevel converter 
To get constant magnitude and frequency AC output, two converters are connected. Fuel cell is connected to a DC-DC boost converter to get adjustable voltage and a DC-AC multilevel converter for staircase voltage output. Fuel cell is modeled using empirical formulae and optimal air and hydrogen inlet flow rates are achieved using current drawn from fuel cell.

\section{CASCADED H BRIDGE CONVERTER}

Cascaded $\mathrm{H}$ bridge converter is composed of multiple units of single phase $\mathrm{H}$ bridge power cells. These $\mathrm{h}$ bridge cells are connected in cascade on their ac side to achieve medium and high power applications and low harmonic distortion as illustrated in Fig. 2. The full-bridge (H-bridge) topology is used to synthesize three unique output voltages $(+\mathrm{Vdc},-\mathrm{Vdc}$ and zero) by connecting the dc source to the ac output side using different combinations of the four switches $\mathrm{S} 1, \mathrm{~S} 2, \mathrm{~S} 3$ and S4. The overall output voltage of multilevel converter is given by:

$$
\begin{aligned}
& V_{\text {Out }}(t)=V_{\text {Outl }}(t)+V_{\text {Out } 2}(t) \\
& +V_{\text {Out } 3}(t)+\ldots \ldots . V_{\text {OutN }}(t)
\end{aligned}
$$

If all dc voltage sources in Fig. 2 are equal to $V_{d c}$, the converter is known as symmetric multilevel converter and the number of output phase voltage levels $\mathrm{N}_{\text {step }}$ in a cascade converter is given by:

$$
N_{\text {step }}=2 n+1
$$

where, ' $n$ ' is the number of separate dc sources (photovoltaic modules or fuel cells or the number of full-bridges) and the maximum output voltage $\left(V_{\text {Outmax }}\right)$ of this ' $n$ ' cascaded multilevel converter is:

$V_{\text {Outmax }}=n * V d c$

To get large number of voltage levels without increasing the number of inverters asymmetric multilevel inverters can be used. For asymmetric cascaded multilevel converter, DC voltage sources of different cells are non-equal. Asymmetric converter provides an increased number of voltage levels for the same number of cells than that of its symmetric counterpart.

Composition of core foods of the USA food supply 1982-1991

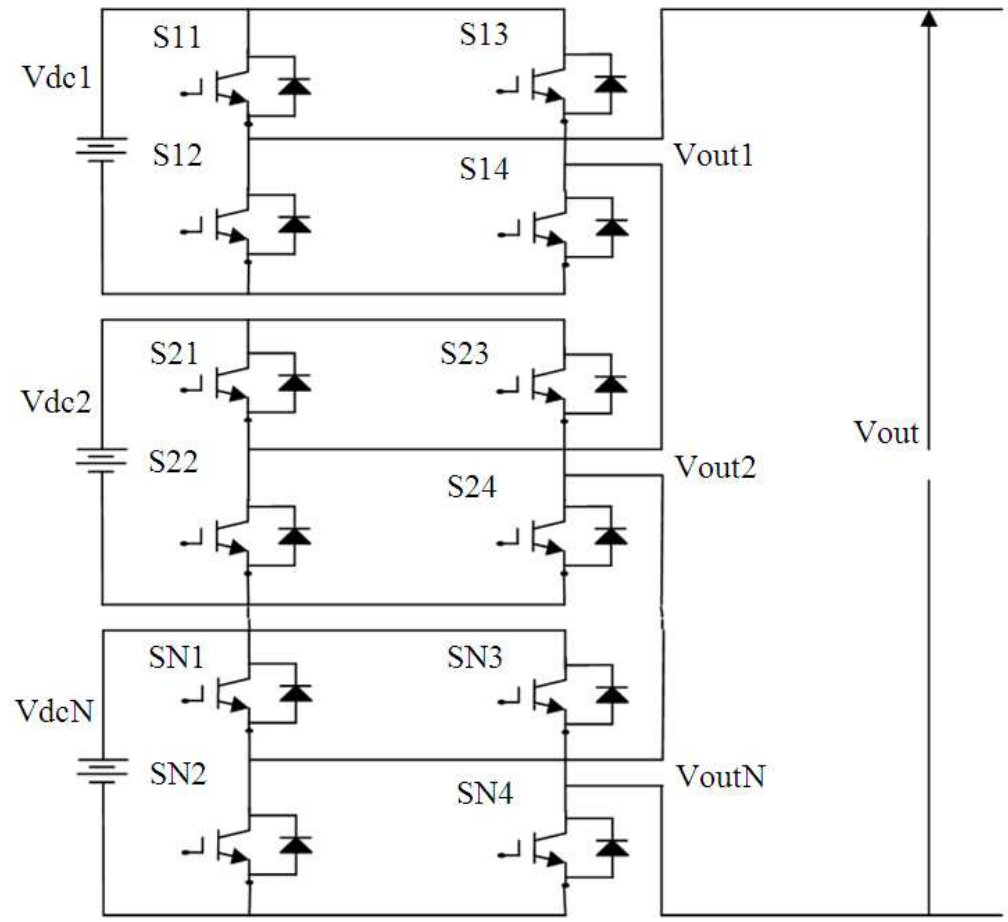

Fig. 2. Configuration of cascaded multilevel converter 
If the DC voltages of individual cells in Fig. 2 are selected according to a geometric progression with a factor of two or three for ' $\mathrm{n}$ ' cascaded multilevel converters, then the number of voltage steps count is:

$$
\begin{aligned}
& N_{\text {step }}=2^{n+1}-1 \text { if } V_{j}=2^{j-1} V_{d c} \text { for } j=1,2, \ldots n 1 \\
& N_{\text {step }}=3^{n+1}-1 \text { if } V_{j}=3^{j-1} V_{d c} \text { for } j=1,2, \ldots n 1
\end{aligned}
$$

The maximum output voltage of these ' $n$ ' cascaded multilevel converters is:

$$
\begin{aligned}
& V_{\text {outmax }}=\left(2^{\mathrm{n}}-1\right) V_{d c} \text { if } V_{j}=2^{\mathrm{j}-1} V_{d c} \text { for } j=1,2, . . n \\
& V_{\text {outmax }}=\left(\frac{3^{n}-1}{2}\right) V_{d c} \text { if } V_{j}=3^{\mathrm{j}-1} V_{d c} \text { for } j=1,2, \ldots n
\end{aligned}
$$

From Equation 2 and 7, it can be seen that the asymmetric multilevel converters can generate more voltage steps and higher maximum output voltage with the same number of bridges.

The number of required switches against required voltage levels is a very important element in the design. To provide a large number of output levels without increasing the number of bridges, a new power circuit topology and a suitable method to determine the dc voltage sources level for symmetrical and asymmetrical multilevel converter are proposed. The proposed circuit also provides decreased voltage stress on the switch by the series configuration of the applied bidirectional switches. Bidirectional switches have the ability to block voltage and conducting current in both directions. Bidirectional switch is arranged by a common emitter connection of two IGBTs, both with antiparallel diode. One gate driver circuit is required by both IGBTs because of common emitter connection (Barriuso et al., 2009).

Figure 3 shows the configuration of the proposed symmetrical multilevel converter with photovoltaic system. Structure of the PV system is explained in the next section. Figure 4 shows the 7-level output voltage wave generated.

For increasing output voltage levels, one power supply shall be added with one switch only. This proposed method is quite different, because it has lesser number of bidirectional switches and different from the conventional converters and methods. The effective number of output voltage steps $\left(\mathrm{N}_{\text {step }}\right)$ in symmetric multilevel converter is:

$$
N_{\text {step }}=2 n+1
$$

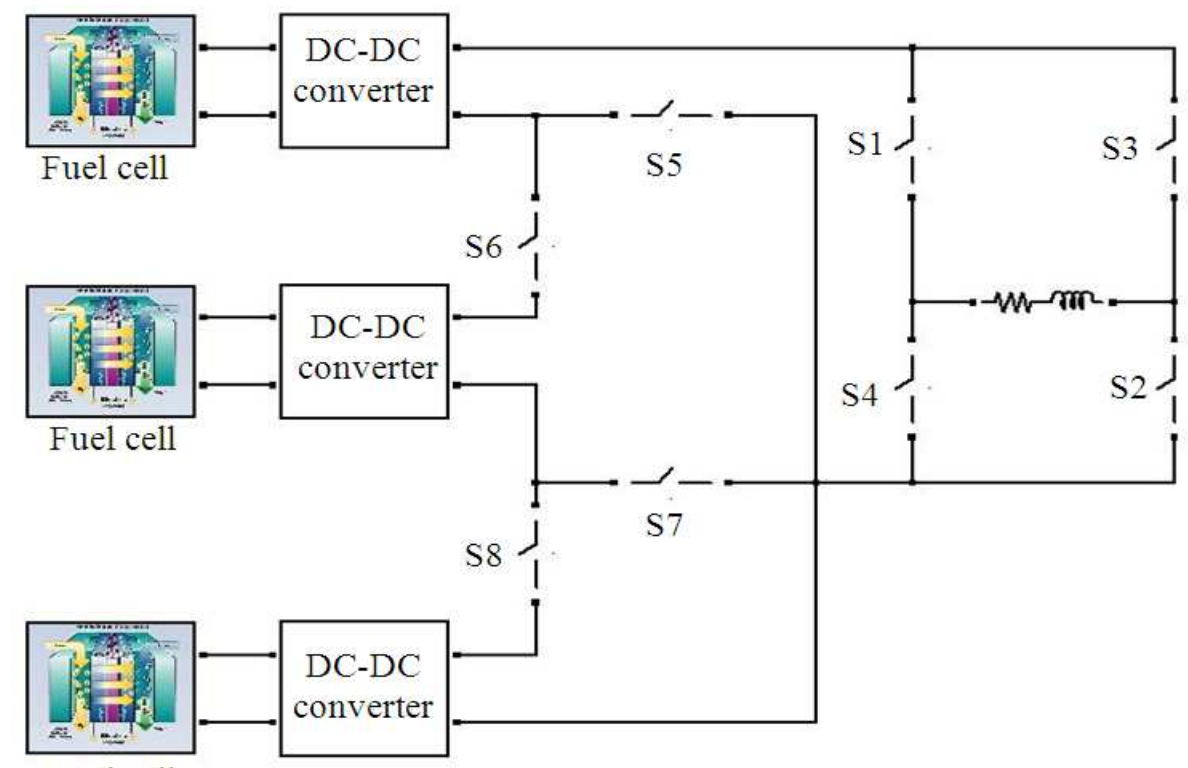

Fuel cell

Fig. 3. Proposed basic topology for a symmetrical converter with Fuel cell system 


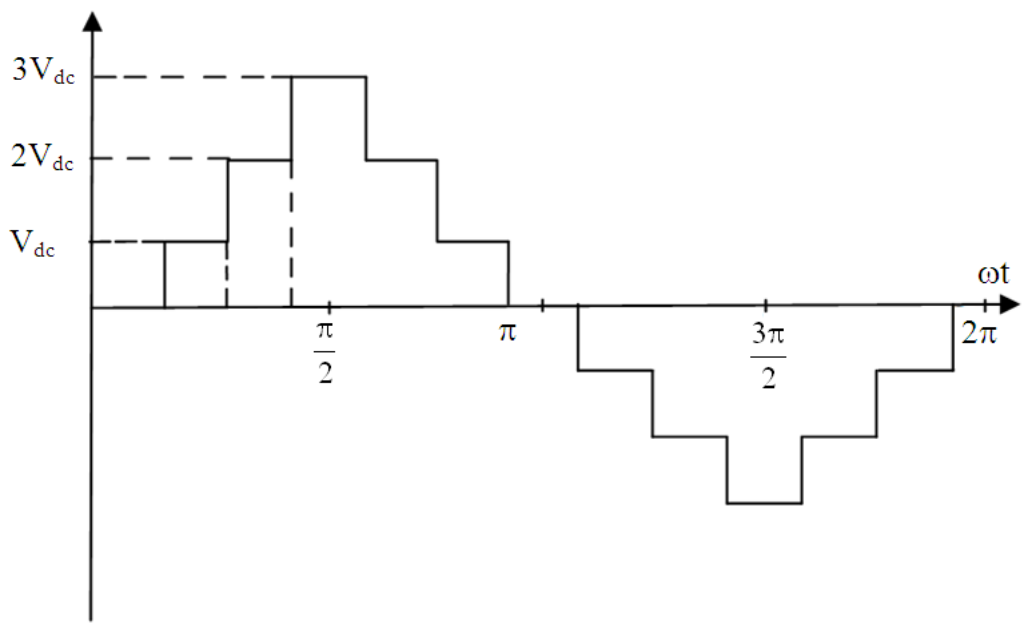

Fig. 4. Typical waveform of 7-level output voltage

where, ' $n$ ' represents the number of dc supplies. The maximum output voltage $\left(\mathrm{V}_{\text {outmax }}\right)$ of this ' $\mathrm{n}$ ' cascaded multilevel converter is:

$V_{\text {outmax }}=(n-1) V d c$

\section{FUEL CELL MODELLING}

A fuel cell is an electrochemical cell that converts a source fuel into an electrical current. It generates electricity inside a cell through reactions between a fuel and an oxidant, triggered in the presence of an electrolyte. The reactants flow into the cell and the reaction products flow out of it, while the electrolyte remains within it. Fuel cells can operate continuously as long as the necessary reactant and oxidant flows are maintained. Fuel cells are different from conventional electrochemical cell batteries in that they consume reactant from an external source, which must be replenished-a thermodynamically open system. By contrast, batteries store electrical energy chemically and hence represent a thermodynamically closed system. Many combinations of fuels and oxidants are possible. A hydrogen fuel cell uses hydrogen as its fuel and oxygen (usually from air) as its oxidant. Other fuels include hydrocarbons and alcohols. Other oxidants include chlorine and chlorine dioxide

Fuel cells come in many varieties; however, they all work in the same sandwiched together: The anode, the electrolyte and the cathode. Two chemical reactions occur at the interfaces of the three different segments. The net result of the two reactions is that fuel is consumed, water or carbon dioxide is created and an electrical current is created, which can be used to power electrical devices, normally referred to as the load. At the anode a catalyst oxidizes the fuel, usually hydrogen, turning the fuel into a positively charged ion and a negatively charged electron. The electrolyte is a substance specifically designed so ions can pass through it, but the electrons cannot. The freed electrons travel through a wire creating the electrical current. The ions travel through the electrolyte to the cathode. Once reaching the cathode, the ions are reunited with the electrons and the two react with a third chemical, usually oxygen, to create water or carbon dioxide.

The Proton Exchange Membrane (PEM) Fuel Cell, developed by NASA in $1960 \mathrm{~s}$, depends on polymer membrane that is coated with highly dispersed catalyst particles. A fuel cell consists of an electrolyte sandwiched between two electrodes. The electrolyte has a special property that allows positive ions (protons) to pass through While blocking electronics. Hydrogen gas passes over one electrode, called an anode and with the help of catalyst, separates into electrons and hydrogen protons:

$$
2 \mathrm{H}_{2} \rightarrow 4 \mathrm{H}^{+}+4 e^{-}
$$

The protons flow to the other electrode, called a cathode, through electrolyte while the electrons flow through an external circuit, thus creating electricity. The hydrogen protons and electrons combine with the oxygen flow through the cathode and produce water. The process of chemical reacttion in fuel cell is shown in Fig 5.

The overall reaction of the fuel cell is therefore: 


$$
2 \mathrm{H}_{2}+\mathrm{O}_{2} \rightarrow 2 \mathrm{H}_{2} \mathrm{O}
$$

The voltage produced from one cell between 0 to 1 volts depending on fuel cell operating conditions and size of load connected to the fuel cell. The typical values of the fuel cell voltage is about 0.7 volts. A single fuel cell produces an output voltage of $0.7 \mathrm{~V}$. For general applications several fuel cells are connected in series to form a fuel stack to produce the required voltage. Typical Characteristics of fuel cells are normally given in the form of polarization curve shown in figure, which is a plot of cell voltage versus cell current density (Current per unit cell active area). In any case, current density of the fuel cell $\mathrm{J}\left(\mathrm{A} / \mathrm{cm}^{2}\right)$ is defined by the following expression:

$$
\mathrm{J}=\frac{\mathrm{I}_{\mathrm{st}}}{\mathrm{A}_{\mathrm{fc}}}
$$

where, $I_{\text {st is the }}$ stack current, $A_{\mathrm{fc}}$ is the fuel cell active area.

The voltage calculated $\mathrm{V}_{\text {cell }}$ represents the voltage of a single fuel cell. Since individual cells are stacked up in series to form a fuel cell stack, the total voltage of stack is calculated by multiplying single cell voltage and the total number of cells in the stack Equation 11:

$$
\mathrm{V}_{\mathrm{st}}=\mathrm{n} \cdot \mathrm{V}_{\text {cell }}
$$

where, $\mathrm{n}$ is the number of fuel cells in the stack.

The Fuel cell polarization curve is the function of cathode pressure, reactant partial pressures and FC temperature and membrane humidity. Fuel cells achieve their highest output voltage at open circuit and the voltage drops off with increasing current draw as shown in Fig. 6.
The unit cell terminal voltage of the fuel cell is represented by subtracting three polarization losses from the open circuit voltage with respect to the exchange current density. The unit cell voltage shows non -linear characteristics. The cell potential $\left(\mathrm{V}_{\text {cell }}\right)$ at any instance can be found using Equation 12:

$$
\mathrm{V}_{\text {cell }}=\mathrm{E}-\mathrm{V}_{\mathrm{act}}-\mathrm{V}_{\text {ohm }}-\mathrm{V}_{\text {conc }}
$$

Where:

$\mathrm{E}=$ The open circuit voltage,

$\mathrm{V}_{\text {act }}=$ The activation loss,

$\mathrm{V}_{\mathrm{ohm}}=$ The ohmic loss,

$\mathrm{V}_{\text {conc }}=$ The concentration loss.

The open circuit voltage (E) as a function of fuel cell Temperature $(\mathrm{T})$ in Kelvin. is given by Nernst Equation 13:

$$
\begin{aligned}
& \mathrm{E}=\mathrm{E}_{0}-\left(0.85 \times 10^{-3}\right)(\mathrm{T}-298.15)+\frac{\mathrm{RT}}{2 \mathrm{~F}} \mathrm{In} \\
& {\left[\frac{\mathrm{P}_{\mathrm{H} 2} \mathrm{P}_{02}^{0.5}}{\mathrm{P}_{\mathrm{H} 20} \mathrm{P}^{0.5}}\right] \text { Volts }}
\end{aligned}
$$

where, $\mathrm{E}_{\mathrm{o}}$ is the reference potential at unity activity, $\mathrm{R}$ is the universal gas constant, The partial pressure, $\mathrm{P}_{\mathrm{H} 2}, \mathrm{P}_{\mathrm{O} 2}$ and $\mathrm{P}_{\mathrm{H} 2 \mathrm{O}}$ of the hydrogen, oxygen and vapor, respectively are expressed in Bar. The relevant parameters values are given in Table 1. The activation drop can be analyzed by Tafel"s equation and the empirical model outlined is considered in this regard. Equation 14 gives the activation voltage drop $\left(\mathrm{E}_{\mathrm{act}}\right)$ :

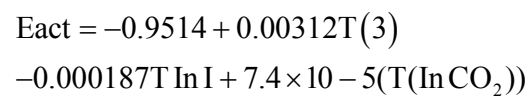

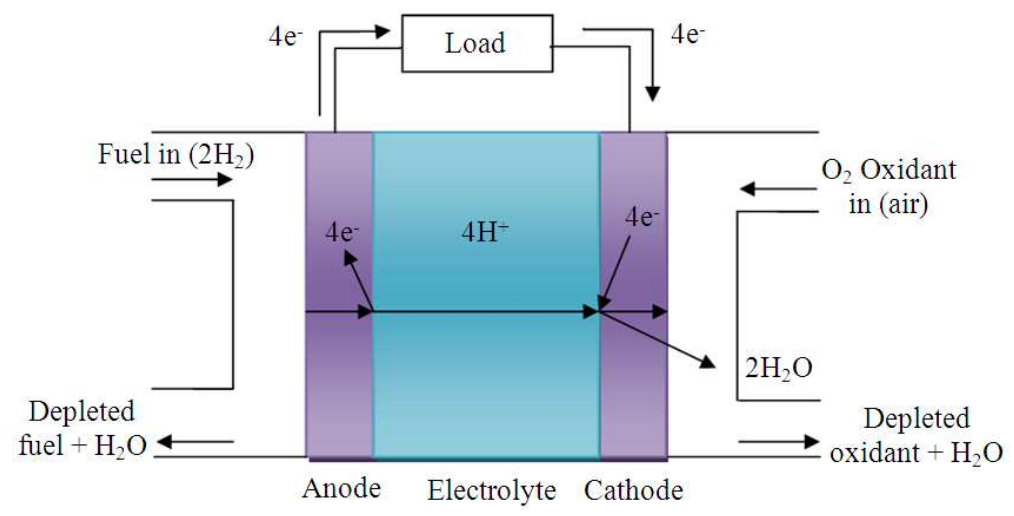

Fig. 5. Electro chemical reaction in PEM fuel cell 


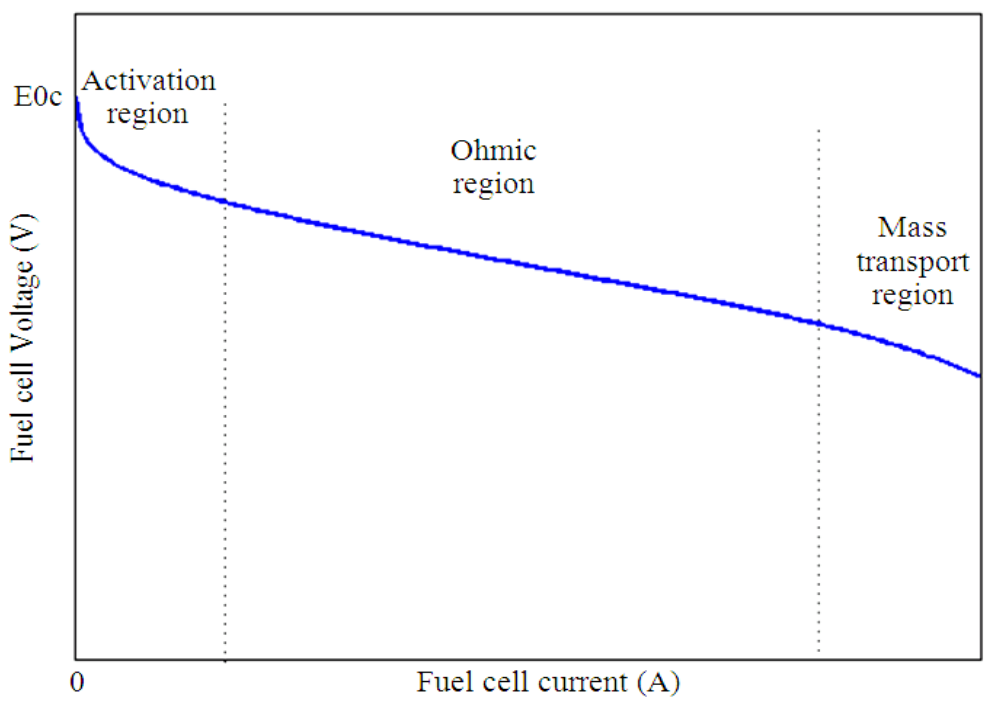

Fig. 6. Polarization curve

Table 1. Fuel cell model parameters

\begin{tabular}{lll}
\hline Symbol & Parameter & Value \\
\hline $\mathrm{P}_{\mathrm{amb}}$ & Ambient pressure & $1 \mathrm{~atm}$ \\
$\mathrm{~V}_{\mathrm{a}}$ & Anode volume & $0.0159 \mathrm{~m}^{3}$ \\
$\mathrm{k}_{\mathrm{a}}$ & Anode flow constant & $0.004 \mathrm{~mol} \mathrm{~s}^{-1} \mathrm{~atm}^{-1}$ \\
$\mathrm{~V}_{\mathrm{c}}$ & Cathode volume & $0.0025 \mathrm{~m}^{3}$ \\
$\mathrm{~K}_{\mathrm{a}}$ & Cathode flow constant & $0.01 \mathrm{~mol} \mathrm{~s}^{-1} \mathrm{~atm}^{-1}$ \\
$\mathrm{PC}_{\mathrm{H} 2}$ & Percentage of $\mathrm{H}_{2}$ (purity) & $99 \%$ \\
$\mathrm{CF}_{\mathrm{H} 2}$ & $\mathrm{H}_{2}$ flow rate conversion factor (SLMP to mol s & \\
$\mathrm{PC}_{\mathrm{O} 2}$ & Percentage of $\mathrm{O}_{2}$ (purity) & $6.85 \times 10^{-4}$ \\
$\mathrm{CF}_{\mathrm{O} 2}$ & $\mathrm{O}_{2}$ flow rate conversion factor (SLMP to mol s & $21 \%$ \\
$\mathrm{P}_{\mathrm{H} 2-\mathrm{O}}$ & $\mathrm{Cathode} \mathrm{vapour} \mathrm{content}_{2}$ ) & $6.804 \times 10^{-4}$ \\
\hline
\end{tabular}

$\mathrm{I}\left(\mathrm{mA} / \mathrm{cm}^{2}\right)$ is the cell current density the Oxygen Concentration $\left(\mathrm{CO}_{2}\right)$ is given as a function of stack temperature in Equation 15:

$$
\mathrm{C} 02=\frac{\mathrm{PO} 2}{5.08 \times \exp (-498 / \mathrm{T})} \text { mole } / \mathrm{cm}^{3}
$$

Since, the activation overvoltage appears as a voltage drop in Equation 12 and $\mathrm{E}_{\text {act }}$ in Equation 14 is negative throughout the whole range, Equation 5 is used to avoid a double negation for the term Equation 16:

$$
\mathrm{V}_{\mathrm{act}}=-\mathrm{E}_{\mathrm{act}} \mathrm{V}
$$

The effects of double layer capacitance charging at the electrode-electrolyte interfaces can be expressed by equation 17 :
$\frac{\mathrm{dV}_{\mathrm{act}}}{\mathrm{dt}}=\frac{1}{\mathrm{C}_{\mathrm{dl}}}-\frac{\mathrm{V}_{\mathrm{act}}}{\mathrm{R}_{\mathrm{act}} \mathrm{C}_{\mathrm{dl}}} \mathrm{V}$

Here $\mathrm{C}_{\mathrm{dl}}$ is the double layer capacitance and $\mathrm{R}_{\mathrm{act}}$ is the activation resistance, found by dividing $\mathrm{V}_{\text {act }}$ with $\mathrm{I}$ Equation 18:

$\mathrm{R}_{\mathrm{act}}=\frac{\mathrm{V}_{\text {act }}}{\mathrm{I}} \mathrm{K} \Omega \cdot \mathrm{cm}^{2}$

It should be noted that, here, $\mathrm{R}_{\text {act }}$ stands for the effective resistance for a given cell current, I and contributes to the activation over voltage $\mathrm{V}_{\text {act }}$. On the other hand, Equation 17 is used to determine $\mathrm{V}_{\text {act }}$ at any instance of time. There fore, these equations need to be used 

current densities the voltage drop is almost linear and ohmic in nature. Membrane resistance $\left(R_{\text {mem }}\right)$ is found by dividing the thickness tm by the membrane conductivity, $\sigma$ $\left(\mathrm{k} \Omega-1 . \mathrm{cm}^{-1}\right)$ Equation 19 and 20:

$$
\begin{aligned}
& \mathrm{V}_{\mathrm{ohm}}=\mathrm{I} \cdot \mathrm{R}_{\mathrm{mem}} \\
& \mathrm{R}_{\mathrm{mem}}=\frac{\mathrm{t}_{\mathrm{m}}}{\sigma} \mathrm{K} \Omega \cdot \mathrm{cm}^{2}
\end{aligned}
$$

The membrane water content depends on various factors, such as water drag from the anode to the cathode due to moving protons, external water content of the reactants and back diffusion of water from the cathode to the anode. Since the effect of water drag is a significant factor, it could be hypothesized that the membrane proton concentration is a function of the cell current density only. An empirical differential equation could be solved to determine proton concentration $\left(\mathrm{C}_{\mathrm{H}^{+}}\right)$, to be used to estimate membrane conductivity $(\sigma)$ Equation 21 and 22:

$$
\begin{aligned}
& \frac{\mathrm{dC}_{\mathrm{H}+}}{\mathrm{dt}}+\frac{\mathrm{C}_{\mathrm{H}+}}{\tau_{\mathrm{H}+}}=\frac{1+\alpha_{\mathrm{H}+} \cdot I^{3}}{\tau_{\mathrm{H}+}} \\
& \sigma=\frac{\mathrm{F}^{2}}{\mathrm{R} \cdot \mathrm{T}} \mathrm{D}_{\mathrm{H}}+\mathrm{C}_{\mathrm{H}+}
\end{aligned}
$$

At higher current densities, the cell potential decreases rapidly due to mass transport limitations cell potential decreases at higher current densities. This linearity is defined as Equation 23:

$$
\mathrm{V}_{\text {conc }}=\alpha \mathrm{e}^{(\mathrm{bl})}
$$

separately and can not be interchanged. At intermediate

Here the coefficient a (V) and b $(\mathrm{cm} 2 / \mathrm{mA})$ vary with temperature and given as:

$$
a=\left(1.1 \times 10^{-4}\right)-1.2 \times 10^{-6}(T-273) b=8 \times 10^{-3}
$$

Equation 1-12 could be solved for cell potential, Vcell, as a function of current density, cell temperature, reactant pressure and membrane hydration. If all the cells are in series, stack output is the product of cell potential and number of cells in the stack $(\mathrm{N})$. Vstack $=$ Vcell $\times 35 \mathrm{~V}$ (13) The reactant flow model parameter is as shown in the Table 2 below.

To determine instantaneous conditions of cell, the conservation of gas reactants are calculated using following formulae.

Anode flow Equation 24-26:

$$
\begin{aligned}
& \frac{\mathrm{V}_{\alpha}}{\mathrm{R} \cdot \mathrm{T}} \frac{\mathrm{dP}_{\mathrm{H} 2}}{\mathrm{dt}}=\mathrm{m}_{\mathrm{H} 2 \text {-in }}-\mathrm{m}_{\mathrm{H} 2 \text {-out }}-\frac{\mathrm{I}}{2 \mathrm{~F}} \\
& \mathrm{~m}_{\mathrm{H} 2 \text {-out }}=\mathrm{k}_{\alpha}\left(\mathrm{P}_{\mathrm{H} 2}-\mathrm{P}_{\text {amb }}\right) \\
& \mathrm{m}_{\mathrm{H} 2-\text { in }}=\mathrm{F} \cdot \mathrm{R}_{\mathrm{H} 2} \cdot \mathrm{PC}_{\mathrm{H} 2} \cdot \mathrm{CF}_{\mathrm{H} 2}
\end{aligned}
$$

Cathode flow Equation 27-31:

$$
\begin{aligned}
& \frac{\mathrm{V}_{\mathrm{c}}}{\mathrm{R} \cdot \mathrm{T}} \frac{\mathrm{dP}_{02}}{\mathrm{dt}}=\mathrm{m}_{02-\text { in }}-\mathrm{m}_{02-\text { out }}-\frac{\mathrm{I}}{4 \mathrm{~F}} \\
& \mathrm{~m}_{02-\text { out }}=\mathrm{k}_{\mathrm{c}}\left(\mathrm{P}_{02}-\mathrm{P}_{\text {amb }}\right) \\
& \mathrm{m}_{02-\text { in }}=\mathrm{F} \cdot \mathrm{R}_{02} \cdot \mathrm{PC}_{02} \cdot \mathrm{CF}_{02} \\
& \frac{\mathrm{V}_{\mathrm{c}}}{\mathrm{R} \cdot \mathrm{T}} \frac{\mathrm{dP}_{\mathrm{H} 20-\mathrm{C}}}{\mathrm{dt}}=\mathrm{m}_{\mathrm{H} 20-\text { in }-\mathrm{c}}-\mathrm{m}_{\mathrm{H} 20-0 \text { out }-\mathrm{C}}+\frac{\mathrm{I}}{2 \mathrm{~F}} \\
& \mathrm{~m}_{\mathrm{H} 20-\text { out-C }}=\mathrm{k}_{\mathrm{c}}\left(\mathrm{P}_{\mathrm{H} 20-\mathrm{C}}-\mathrm{P}_{\text {amb }}\right)
\end{aligned}
$$

Table 2. Reactant flow model parameters

\begin{tabular}{lll}
\hline Symbol & Parameter & Value \\
\hline $\mathrm{P}_{\mathrm{amb}}$ & Ambient pressure & $1 \mathrm{~atm}$ \\
$\mathrm{~V}_{\mathrm{a}}$ & Anode volume & $0.0159 \mathrm{~m}^{3}$ \\
$\mathrm{k}_{\mathrm{a}}$ & Anode flow constant & $0.004 \mathrm{~mol} \mathrm{~s}^{-1} \mathrm{~atm}^{-1}$ \\
$\mathrm{~V}_{\mathrm{c}}$ & Cathode volume & $0.0025 \mathrm{~m}^{3}$ \\
$\mathrm{~K}_{\mathrm{a}}$ & Cathode flow constant & $0.01 \mathrm{~mol} \mathrm{~s}^{-1} \mathrm{~atm}^{-1}$ \\
$\mathrm{PC}_{\mathrm{H} 2}$ & Percentage of $\mathrm{H}_{2}$ (purity) & $99 \%$ \\
$\mathrm{CF}_{\mathrm{H} 2}$ & $\mathrm{H}_{2}$ flow rate conversion factor (SLMP to mol sec & $6.85 \times 10^{-4}$ \\
$\mathrm{PC}_{\mathrm{O} 2}$ & Percentage of $\mathrm{O}_{2}$ (purity) & $21 \%$ \\
$\mathrm{CF}_{\mathrm{O} 2}$ & $\mathrm{O}_{2}$ flow rate conversion factor (SLMP to mol sec $\mathrm{se}^{-1}$ ) & $6.804 \times 10^{-4}$ \\
$\mathrm{P}_{\mathrm{H} 2 \mathrm{O}-\mathrm{C}}$ & Cathode vapour content & $1 \%$ \\
\hline
\end{tabular}




\section{COMPUTER SIMULATION}

In order to analyze the operation of the proposed fuel cell power conditioning system, the modeling of the fuel cell was carried out. The electrical characteristics of the fuel cell is represented by a mathematical model described in (Marchesoni et al., 1988). Science the unit cell has a low output voltage and a small current rating, many unit cells are connected in series to form a stack structure to build up a reasonable voltage. Many computer simulations were carried out with Mat lab/simulink software to verify the operation of the proposed power conditioning system. The simulation model consists of a fuel cell stack model, DC-DC converters and a multi level inverter. The objective of this section is to evaluate the performance of the proposed fuel cell based multilevel inverter and comparing the results between five levels and seven levels by simulating the system using MATLAB/SIMULINK.

\subsection{Case Study 1: Five Level Inverter}

Five level inverter using 2 Fuel cells and 6 switches shown in Fig. 7. Boost converter is connected to fuel cell to get adjustable DC voltage. Converted voltage by five level converter, filtered voltage and filtered current are shown in Fig. 9. FFT analysis of five level voltage, filtered voltage and filtered current are shown in Fig. 10-12. The MATLAB circuit used for genarating gate pulse for five level converter is shown in Fig. 8. The THD of five level voltage is $26.86 \%$ and filtered voltage is $2.81 \%$.

\subsection{Case Study 2: Seven Level Inverter}

Seven level inverter using $3 \mathrm{PV}$ modules and 8 switches shown in Fig. 13. Converted voltage by this converter with seven levels, filtered voltage and filtered current are shown in Fig. 15. As compared with five level, increase in active power, showing efficient utilization of PV modules in seven level inverter. FFT analysis of seven level voltage, filtered voltage and filtered current are shown in Fig. 16-18. The MATLAB circuit used for genarating gate pulse for seven level converter is shown in Fig.14. The THD of seven level voltage is $18.19 \%$ and filtered voltage is $1.87 \%$. Reduction in harmonics showing improvement of both current and voltage waveform in seven level compared with five level converter.

By comparing the 5 and 7 level multilevel converters response of the high level converter is more accurate than low level converters and Total Harmonic Distortion (THD) is very low for high level converter, the THD response for both converters as shown in the below Table 3.

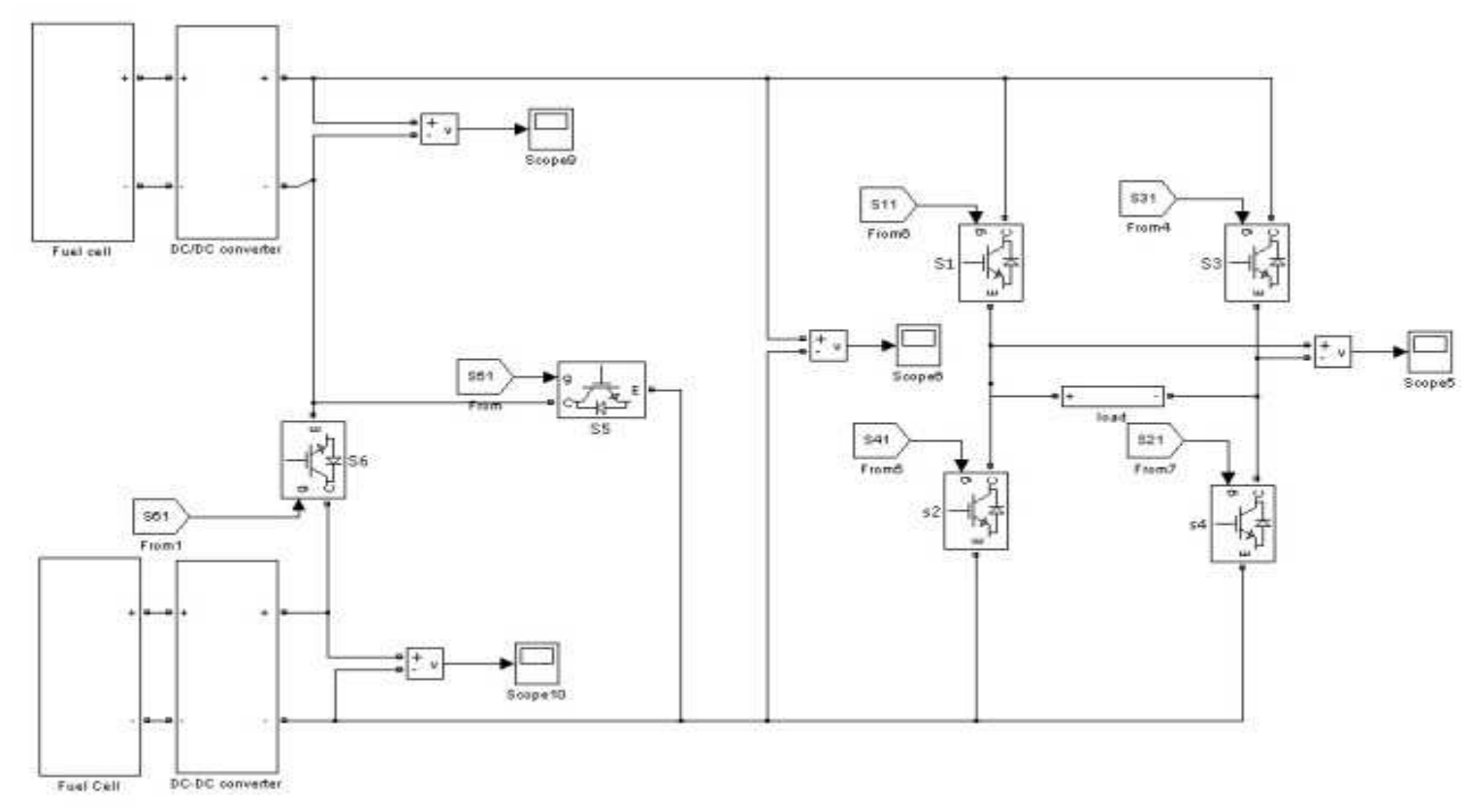

Fig. 7. Simulation model of proposed 5 level converter 


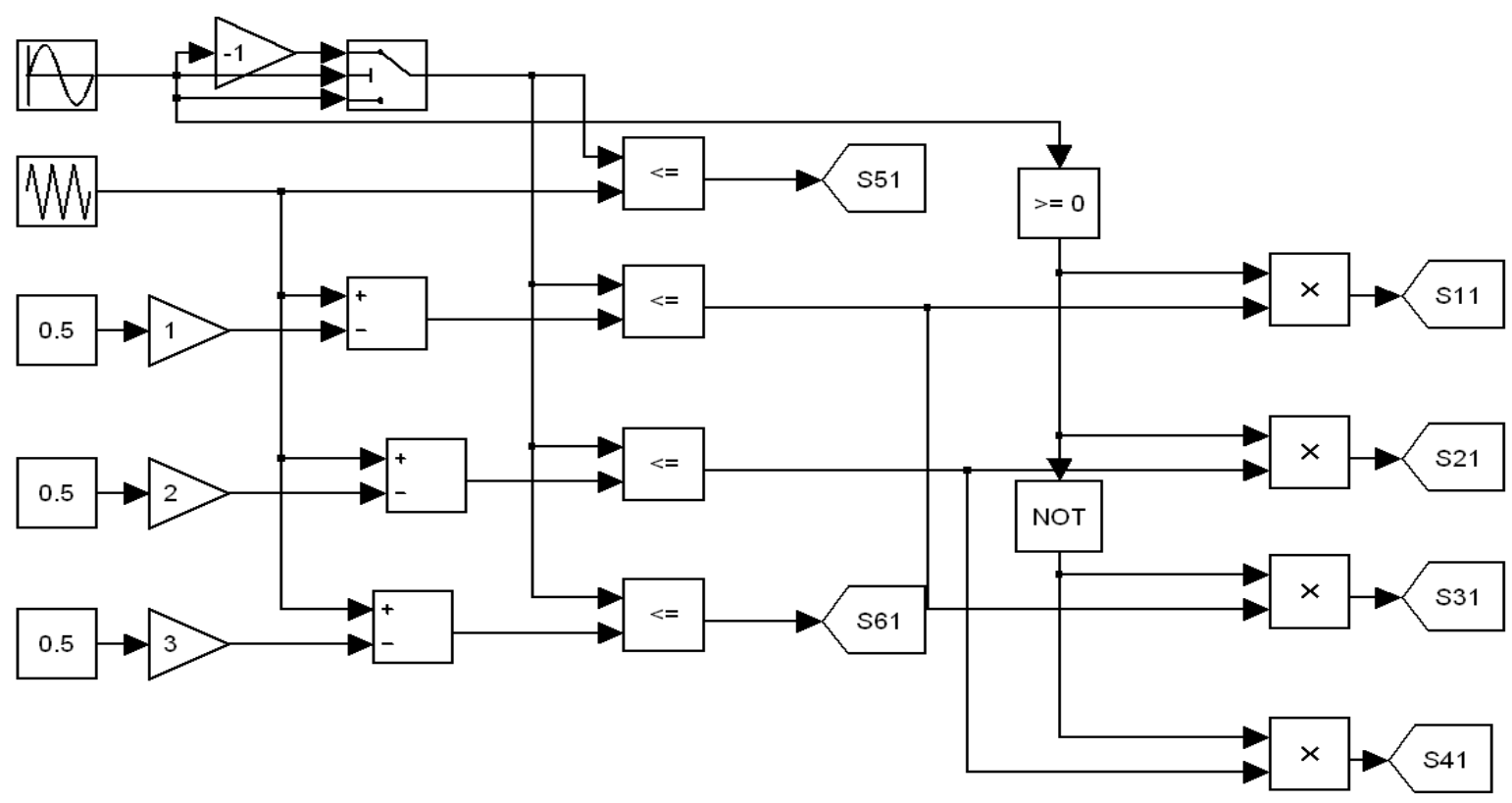

Fig. 8. Pulse generation for five level converter
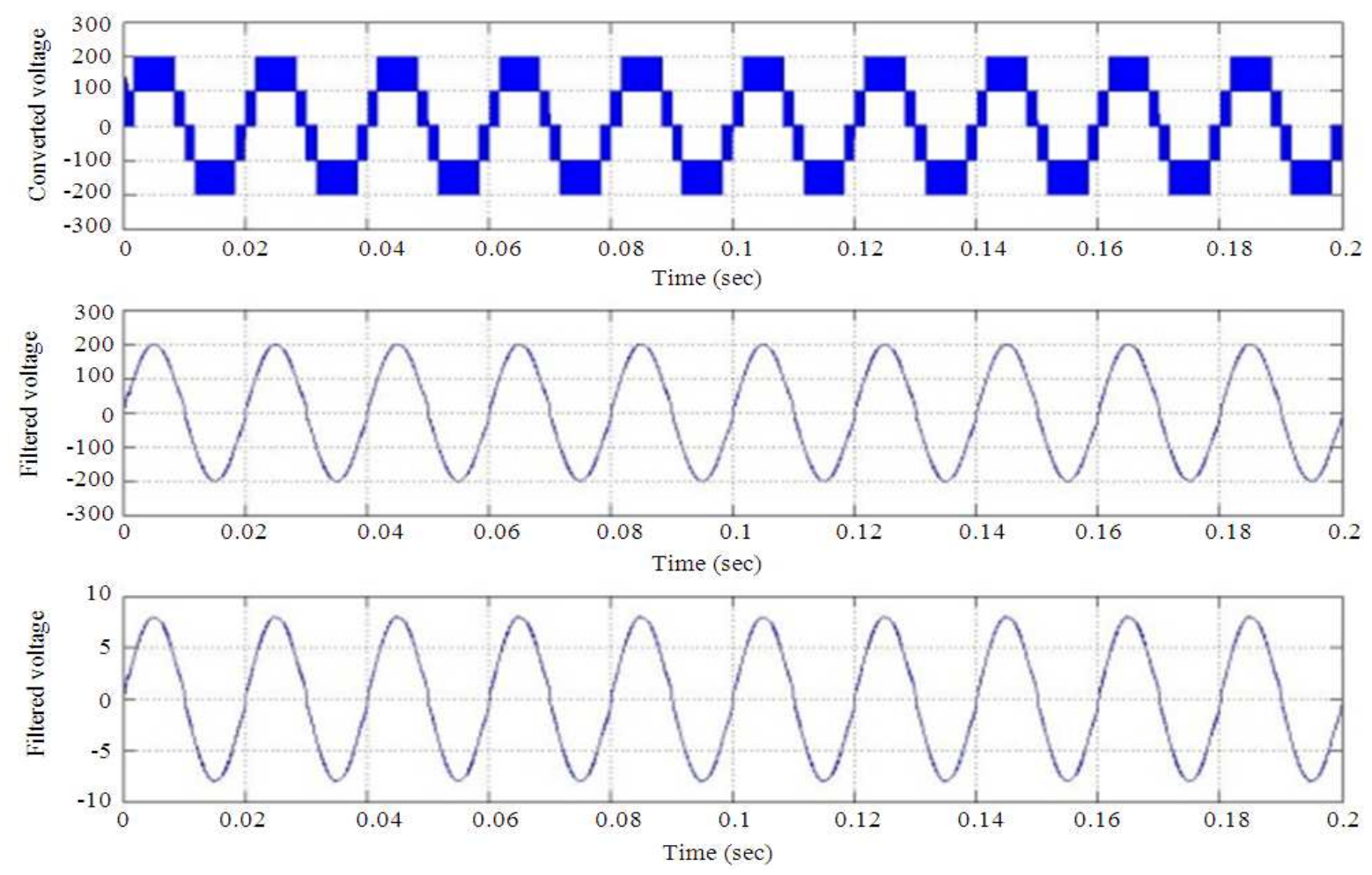

Fig. 9. Input voltage, filtered load voltage and filtered load current for 5 level Inverter 
Prasada Rao, K. and Sukhdeo Sao / American Journal of Applied Sciences 11 (6): 978-993, 2014
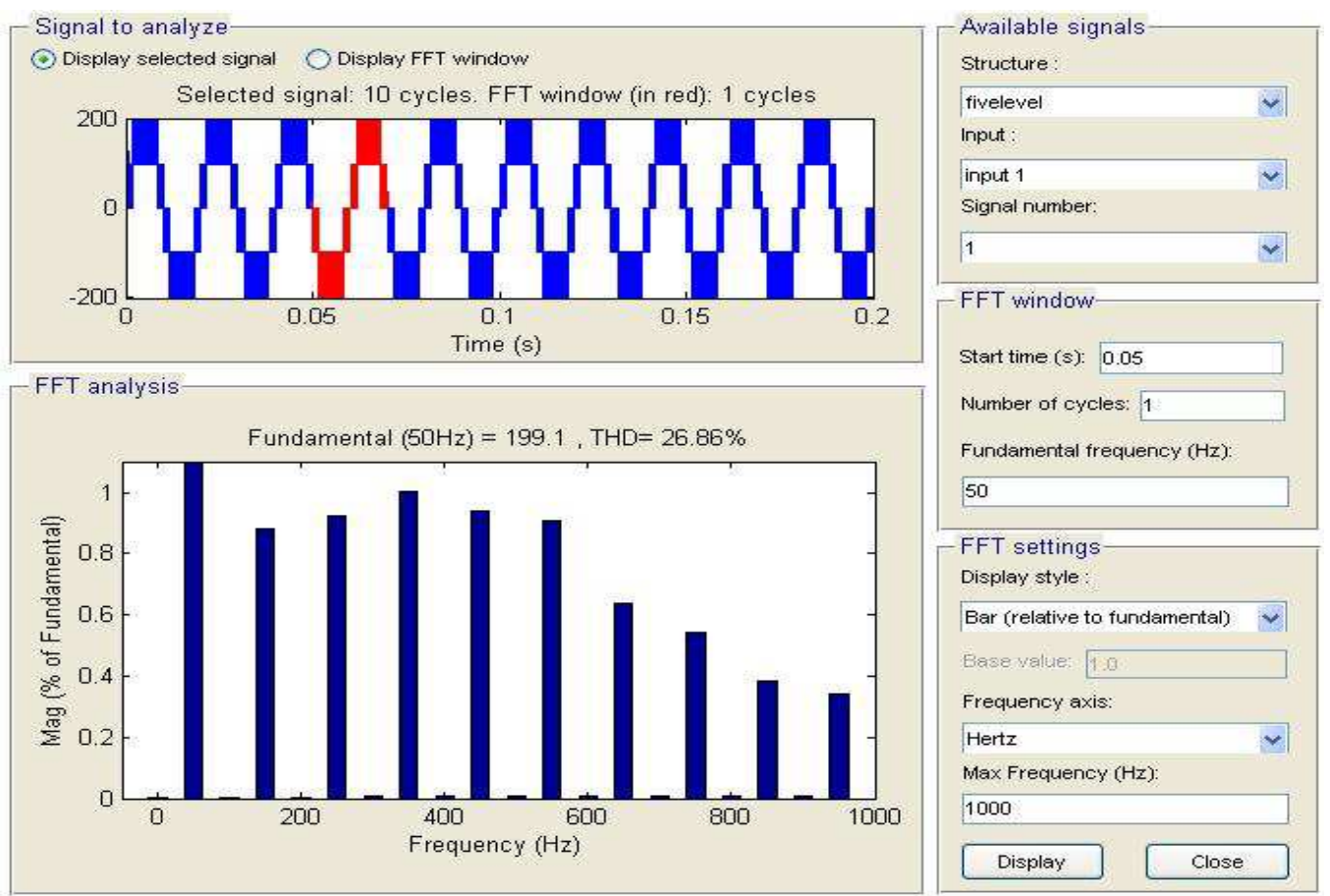

Fig. 10. Input voltage THD response
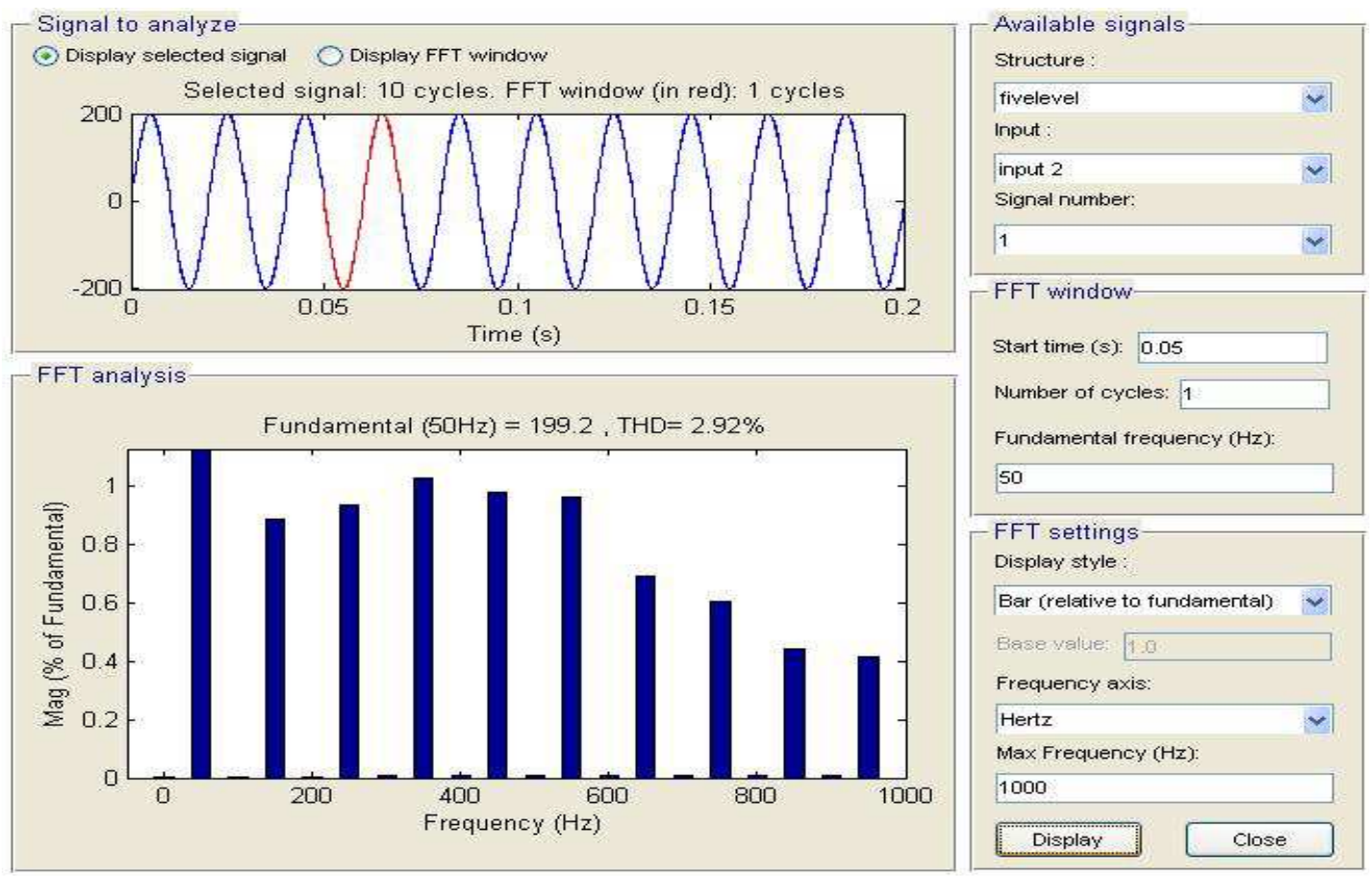

Fig. 11. Load voltage THD response 
Prasada Rao, K. and Sukhdeo Sao / American Journal of Applied Sciences 11 (6): 978-993, 2014
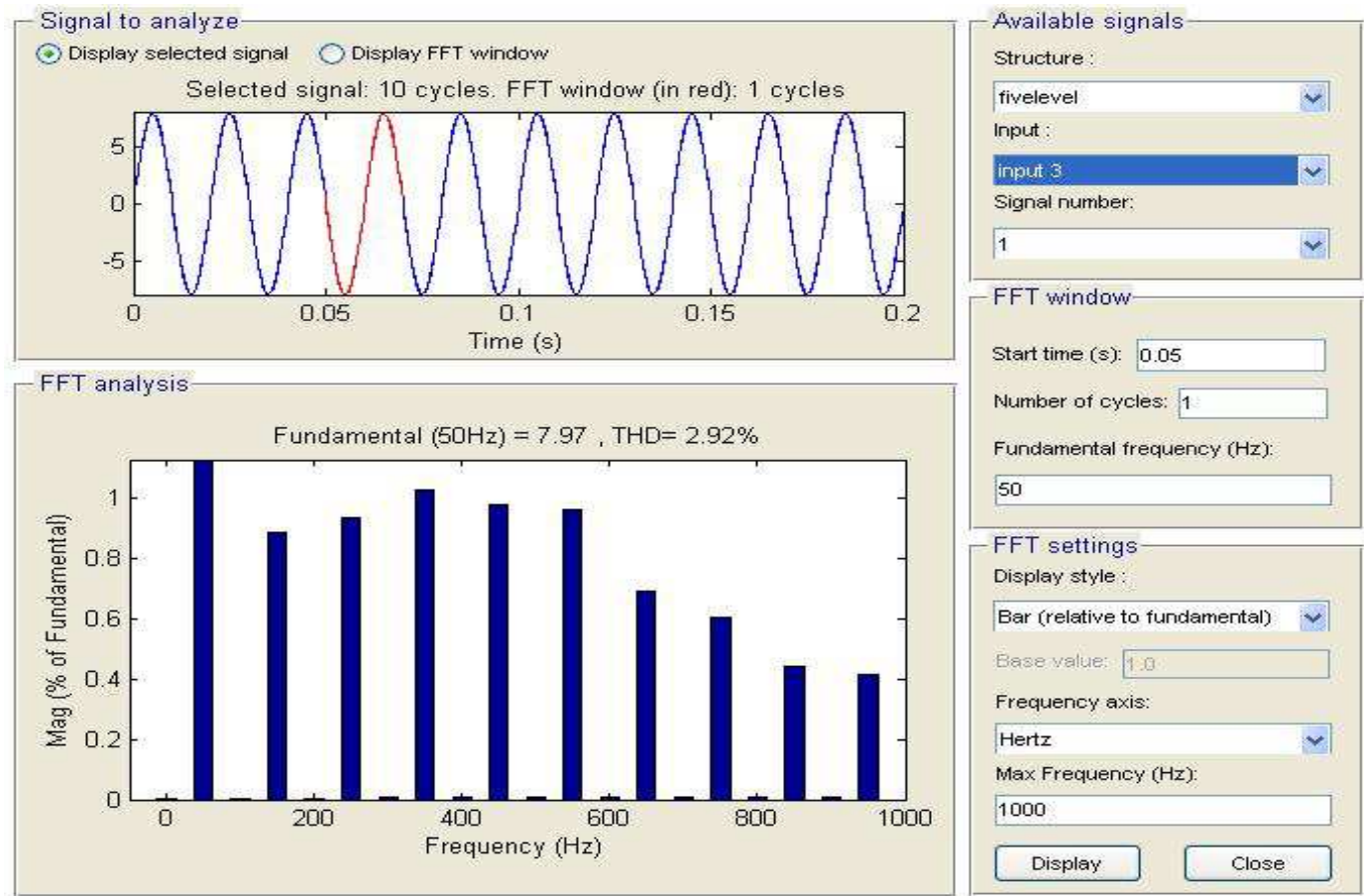

Fig. 12. Load current THD response

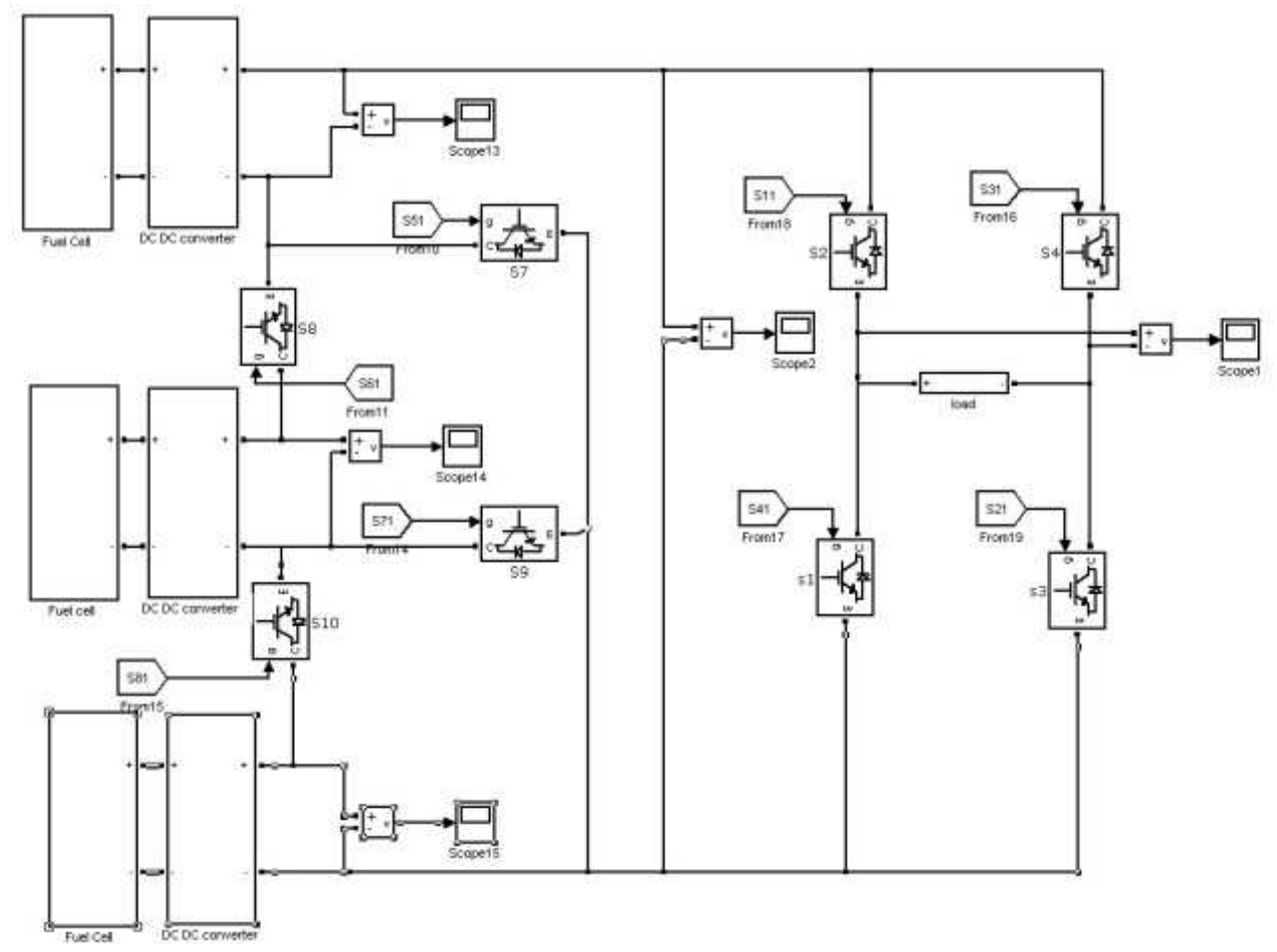

Fig. 13. Simulation model proposed 7 level inverter 


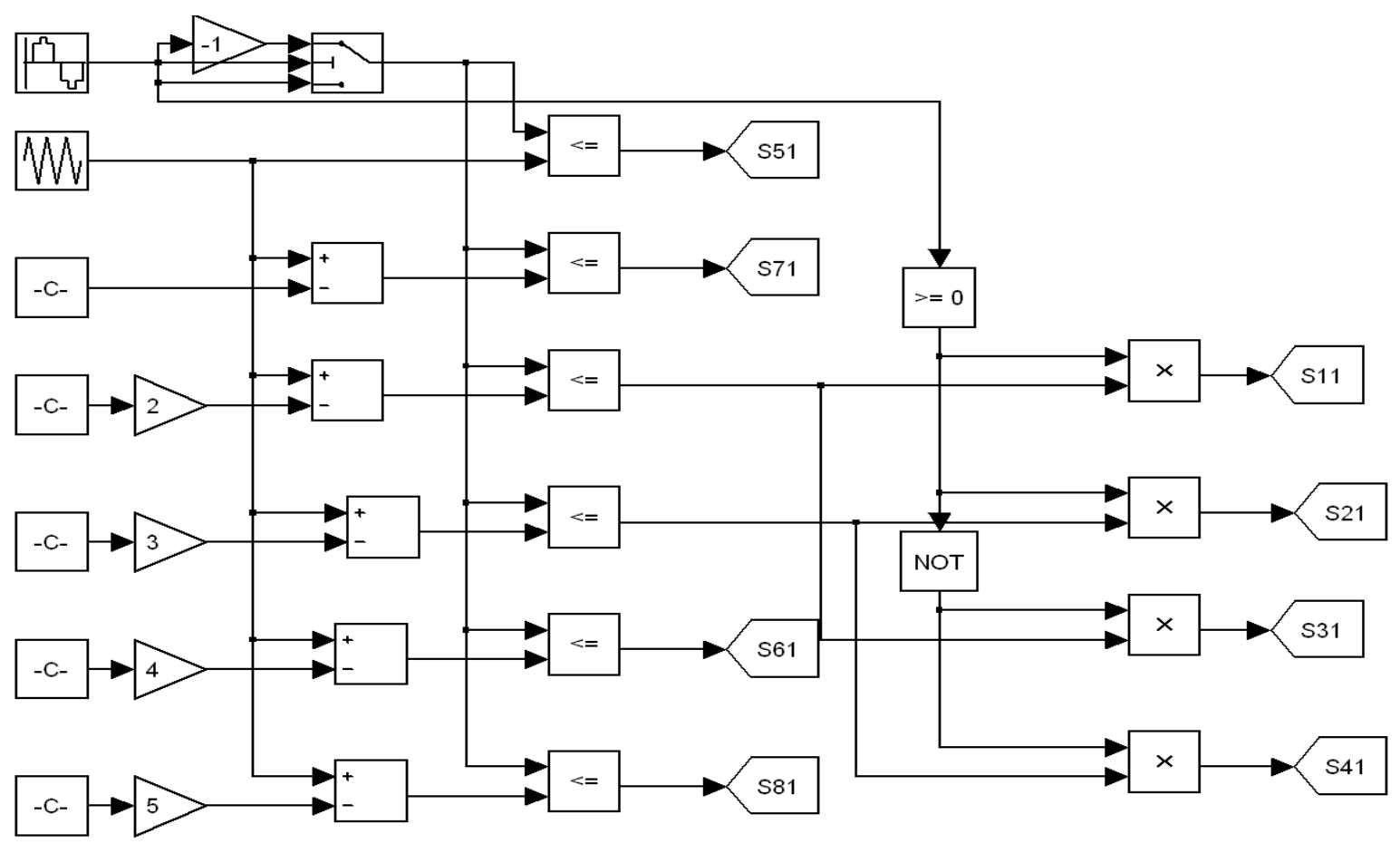

Fig.13 Simulation model of proposed 7 level converter

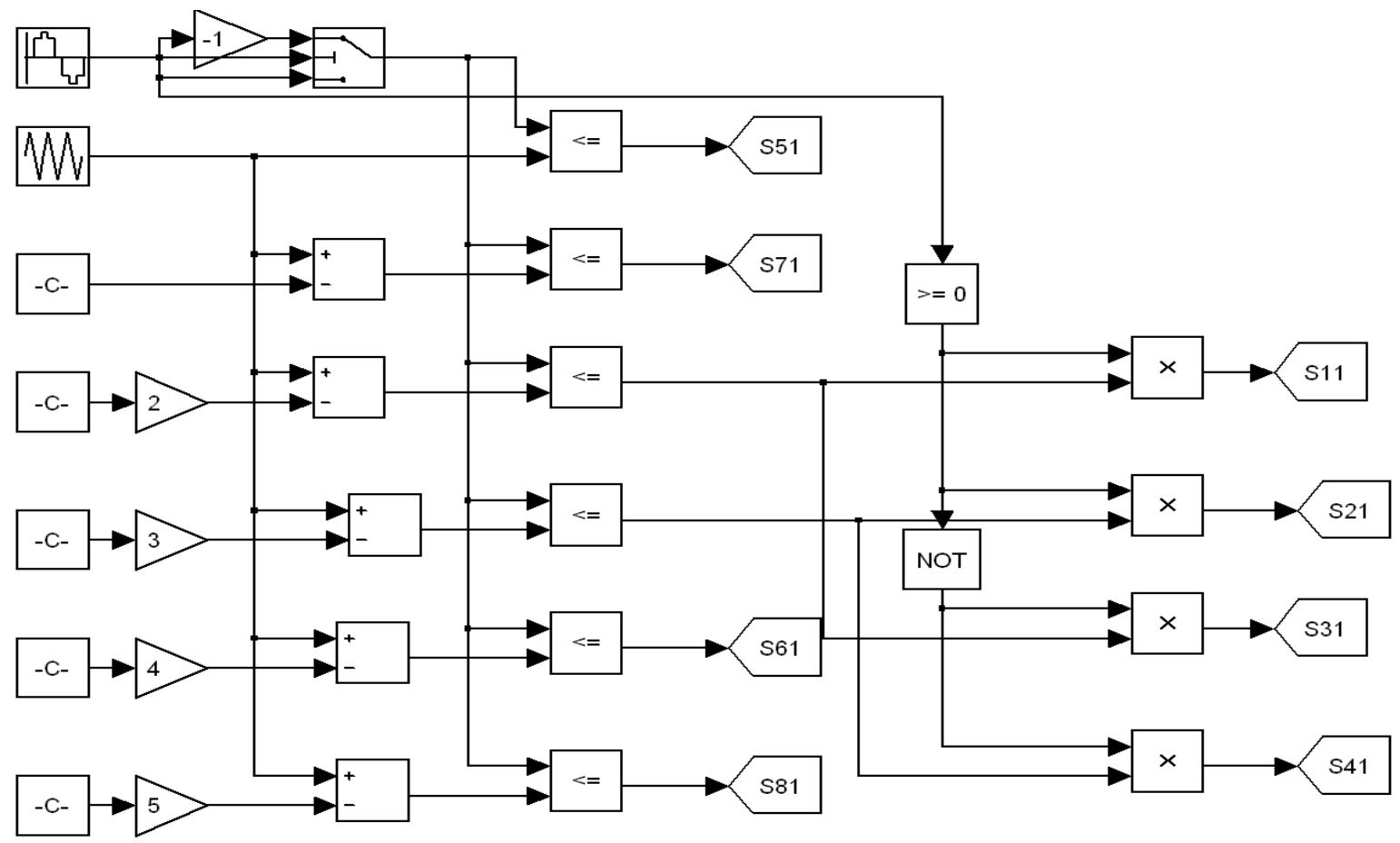

Fig. 14 Pulse generation for seven level converter 
Prasada Rao, K. and Sukhdeo Sao / American Journal of Applied Sciences 11 (6): 978-993, 2014
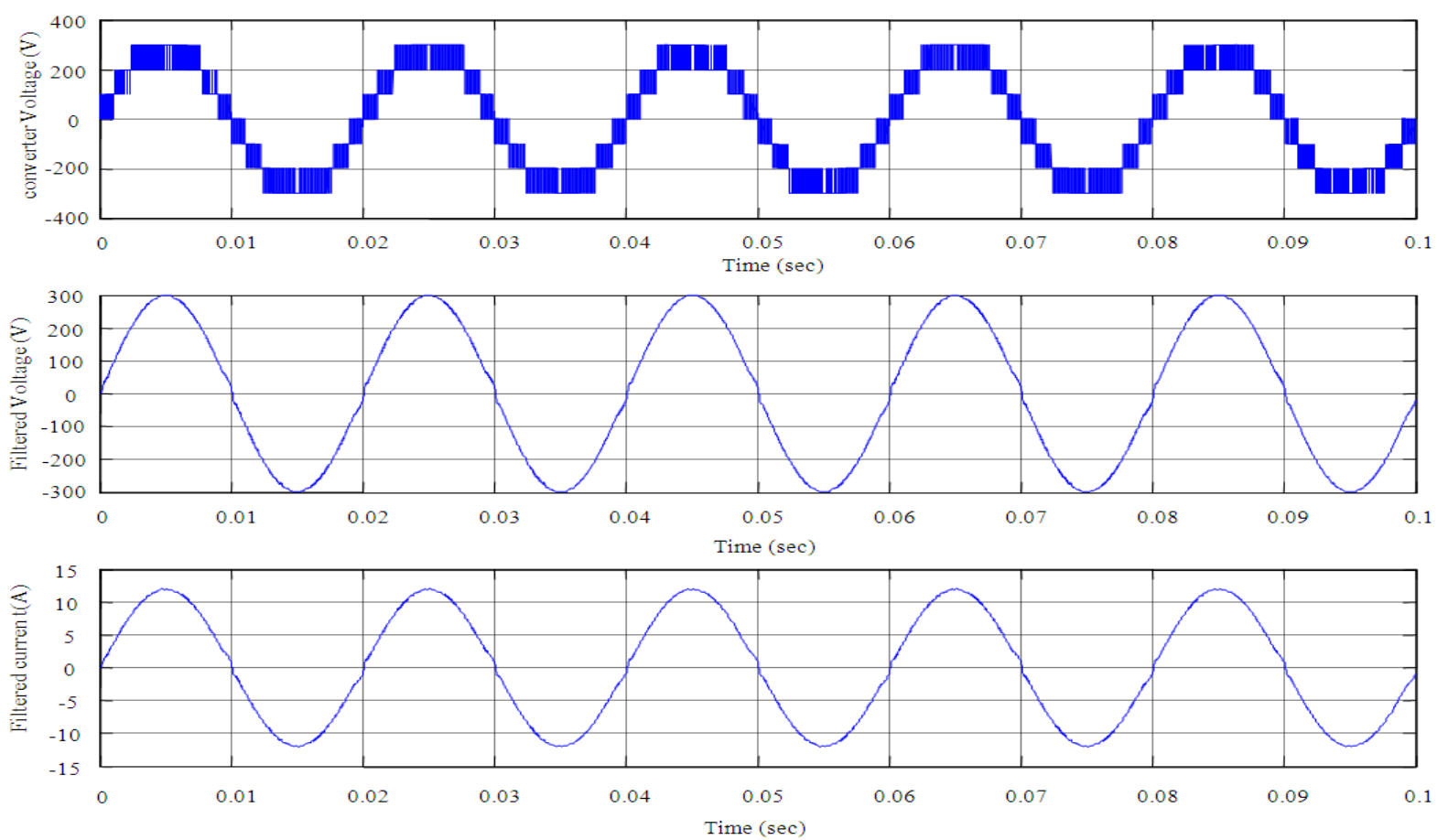

Fig. 15. Input voltage, load voltage and load current for 7 level converter
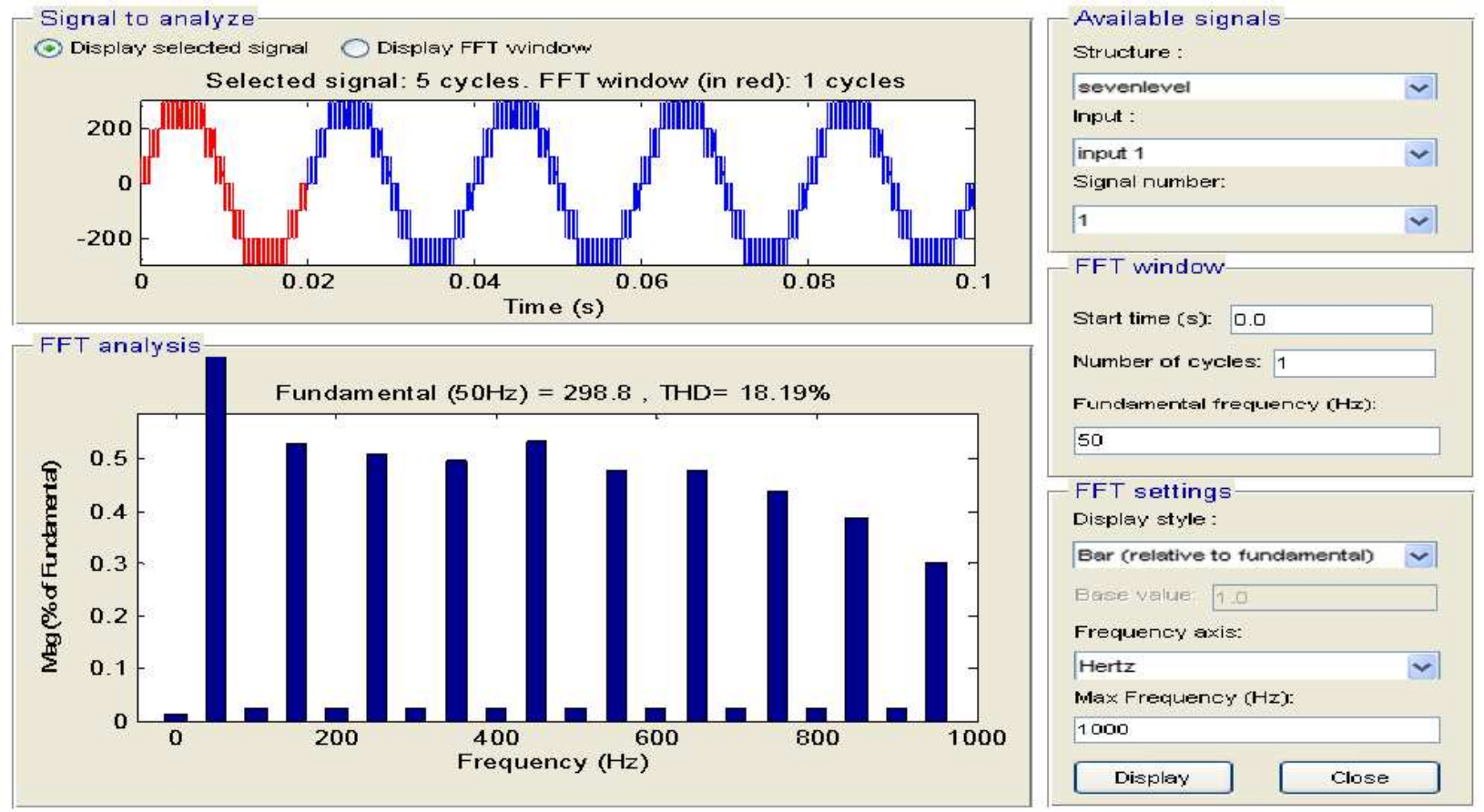

Fig. 16. Input voltage THD response 
Prasada Rao, K. and Sukhdeo Sao / American Journal of Applied Sciences 11 (6): 978-993, 2014
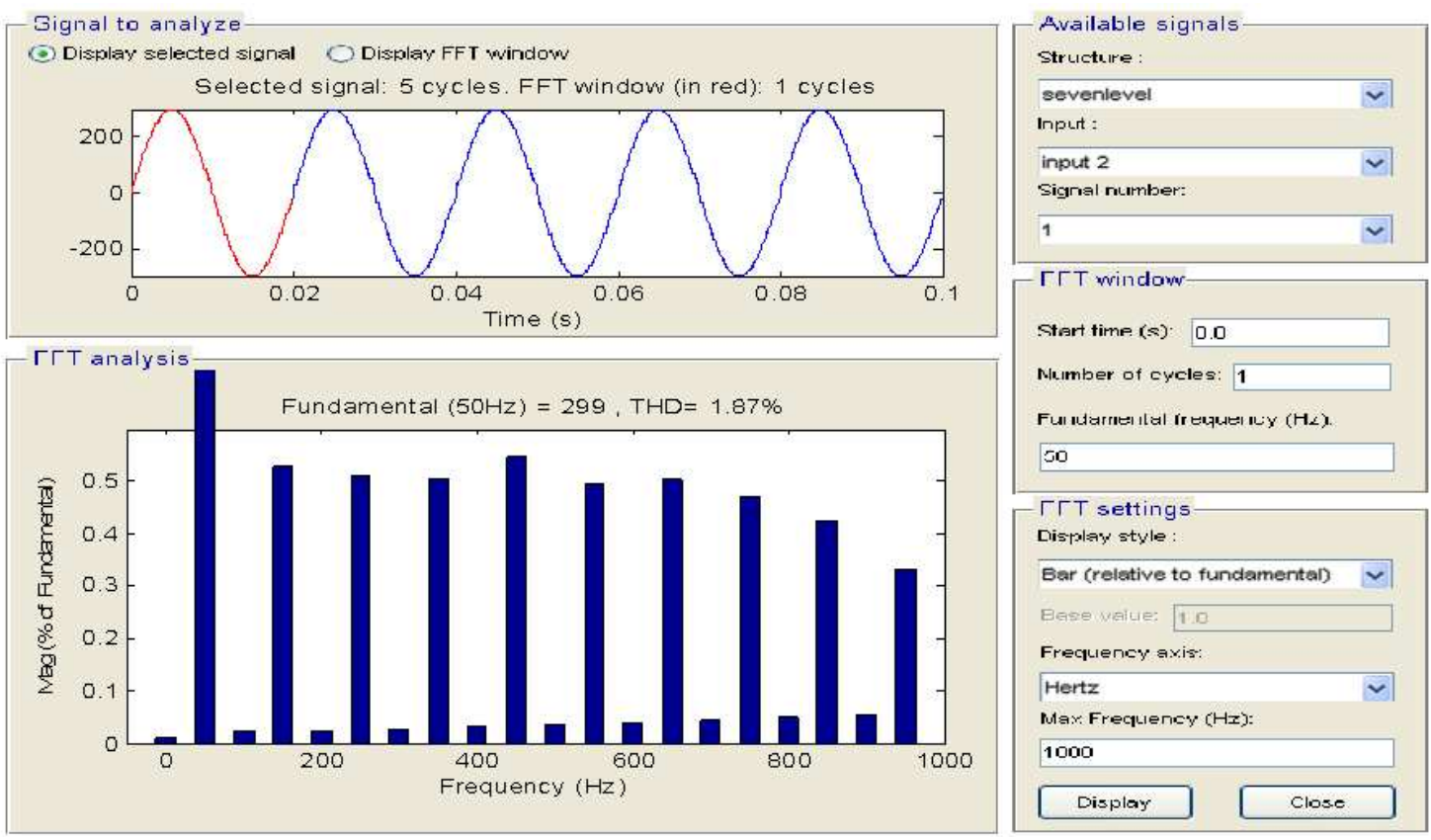

Fig. 17. Load voltage THD response
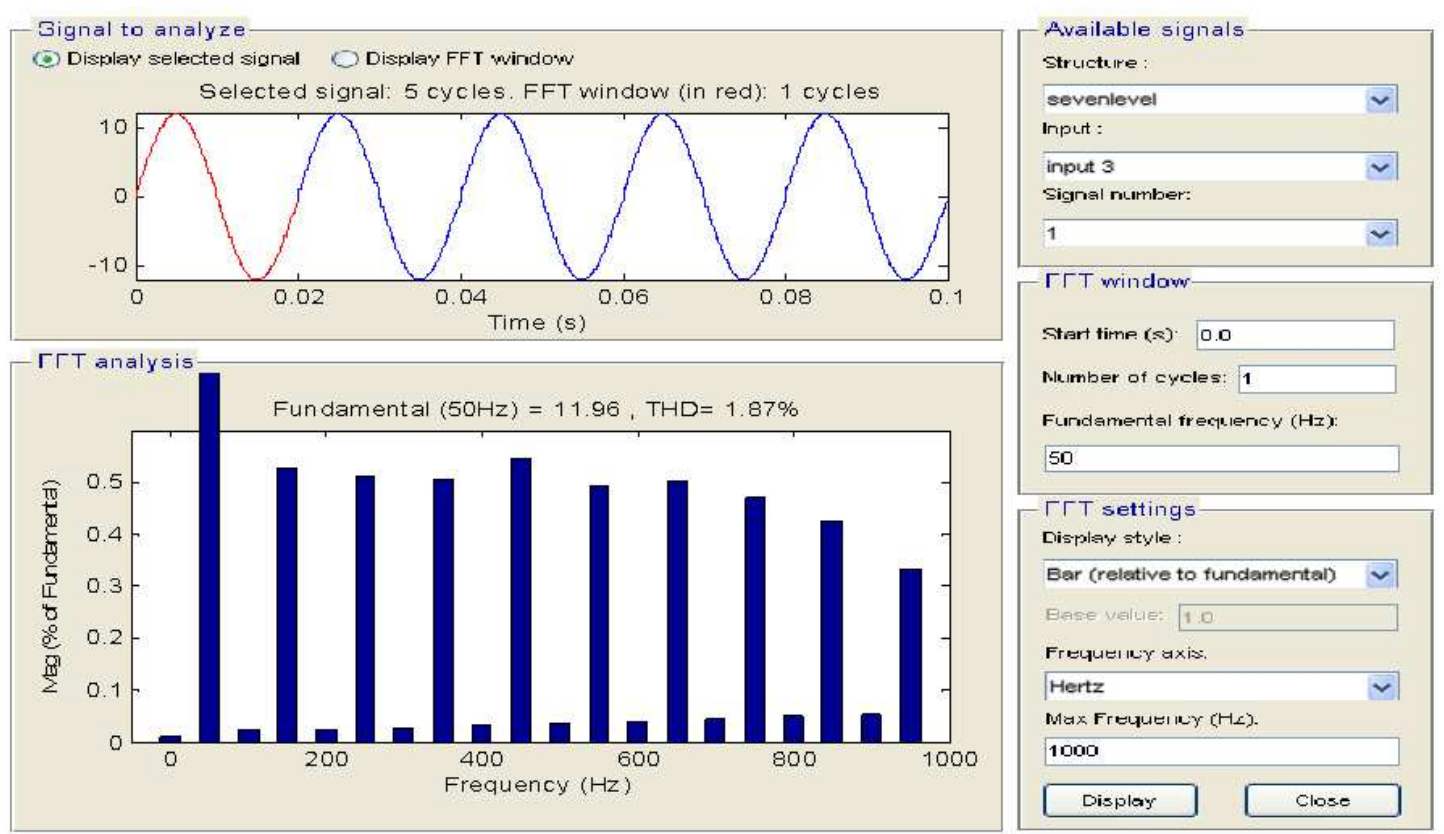

Fig. 18. Load current THD response

Table 3. Total harmonic distortion

\begin{tabular}{llll}
\hline Levels & Converter voltage & Filtered voltage & Filtered current \\
\hline 5 & 26.86 & 2.92 & 2.92 \\
7 & 18.19 & 1.96 & 1.96 \\
\hline
\end{tabular}

\section{CONCLUSION}

This study investigated the fuel cell power conditioning system with multilevel converter. This 
proposed topology extends the design flexibility and the possibilities to optimize the converter for various objectives, such as the minimization of the number of switches, gate driver circuits and capacitors and blocking voltage on switches. Here fuel cells are used as dc source for multilevel converter will reduces the cost of the converter. Based on presented switching algorithm, the multilevel converter generates nearly sinusoidal output voltage and as a result, it has very low harmonic content. This topology provides more flexibility to designers and can generate more voltage levels without losing any level and shows lower THD characteristics and these compared for both 5 and 7 levels. The possibility of extension or series connection of this basic unit in two topologies has been studied. The operation and performance of the proposed topology has been verified by simulation results by comparing with 5 and 7 levels. Reduction of the power losses of the proposed topology in comparison other topology is another advantage of the proposed converter.

\section{REFERENCES}

Babaei, E. and M.S. Moeinian, 2010. Asymmetric cascaded multilevel inverter with charge balance control of a low resolution symmetric subsystem. J. Energy Convers. Manag., 51: 2272-2278. DOI: 10.1016/j.enconman.2010.03.022

Babaei, E. and S.H. Hosseini, 2009. New cascaded multilevel inverter topology with minimum number of switches. J. Energy Convers. Manage., 50: 27612767. DOI: 10.1016/j.enconman.2009.06.032

Barriuso, P., J. Dixon, P. Flores and L. Moran, 2009. Fault-tolerant reconfiguration system for asymmetric multilevel converters using bidirectional power switches. IEEE Trans. Ind. Electron., 56: 1300-1306. DOI: 10.1109/TIE.2008.2005680
Fazel, S.S., S. Bernet, D. Krug and K. Jalili, 2007. Design and comparison of $4-\mathrm{kV}$ neutral-pointclamped, flying-capacitor and series-connected $\mathrm{H}$ bridge multilevel converters. IEEE Trans. Ind. Applic., 43: 1032-1040. DOI: 10.1109/TIA.2007.900476

Gou, B., W. Na and B. Diong, 2010. Fuel Cells: Modeling, Control and Applications. 1st Edn., Taylor and Francis Group, Boca Raton, ISBN-10: 1420071610, pp: 234.

Kazerani, M. and P. Paramita, 2011. Dynamic modeling and performance analysis of a grid-connected current-source inverter-based photovoltaic system. IEEE Trans. Ind. Appl.

Marchesoni, M., M. Mazzucchelli and S. Tenconi, 1988. A non conventional power converter for plasma stabilization. Prcoeedings of the 19th Annual IEEE Power Electronics Specialists Conference, Apr. 1114, IEEE Xplore Press, Kyoto, Japan, pp: 122-129. DOI: 10.1109/PESC.1988.18125

McGrath, B.P. and D.G. Holmes, 2008. Analytical modelling of voltage balance dynamics for a flying capacitor multilevel converter. IEEE Trans. Power Electron., 23: 543-550. DOI: 10.1109/TPEL.2007.915175

Meynard, T.A. and H. Foch, 1992. Multi-level choppers for high voltage applications. Proc. Eur. Conf. Power Electron. Appl., 2: 45-50.

Nabae, A., I. Takahashi and H. Akagi, 1981. A new neutral-point-clamped PWM inverter. IEEE Trans. Ind. Applic., IA-17: 518-523. DOI: 10.1109/TIA.1981.4503992

Tanrioven, M. and M.S. Alam, 2006. Reliability modeling and analysis of stand-alone PEM fuel cell power plants. Renewable Energy, 31: 915-933. DOI: 10.1016/j.renene.2005.05.004 